\title{
Effects of Fertilization on Growth of Zinnia elegans L. Seedlings Grown in Floating System
}

\author{
Anastasia AKOUMIANAKI-IOANNIDOU ${ }^{1 *}$, Roxani-Paraskevi SPENTZA ${ }^{1}$, Ioannis ROUSSIS ${ }^{2}$, Dimitrios \\ BILALIS $^{2}$
}

\begin{abstract}
${ }^{1}$ Agricultural University of Athens, School of Agriculture, Engineering and Environmental Sciences, Department of Crop Science, Laboratory of Floriculture and Landscape Architecture, 75 Iera Odos Str., 11855 Athens, Greece.

${ }^{2}$ Agricultural University of Athens, School of Agriculture, Engineering and Environmental Sciences, Department of Crop Science, Laboratory of Agronomy, 75 Iera Odos Str., 11855 Athens, Greece. "corresponding author: akouman@aua.gr
\end{abstract}

BulletinUASVM Horticulture 76(1) / 2019

Print ISSN 1843-5254, Electronic ISSN 1843-5394

DOI:10.15835/buasvmcn-hort: 2018.0029

\begin{abstract}
The floating system is a promising alternative type of hydroponic seedling production system, which has not been much studied and disseminated in the flower industry. This study aimed to produce seedlings of Zinnia elegans in a floating system and to evaluate the influence of two organic (Codaphos \& Codasting and Fish-Fert) and one inorganic nutrient solution formulations on the seedling growth parameters. Z. elegans seeds germinated at a high rate (76.6-82.1\%) in all fertilization treatments with a $\mathrm{T}_{50}$ ranging from 9.54 to 10.50 days. Application of Codaphos and Codasting (organic fertilizer containing $\mathrm{N}$ - Codasting and $\mathrm{P}+\mathrm{K}$ - Codaphos) in floating system resulted in better development of the aboveground parts and roots of seedlings comparing with the other organic and the inorganic fertilization. As a conclusion, the present study showed that organic fertilization, especially with Codaphos and Codasting, could successfully be used for the production of Z. elegans seedlings in a floating system; however, further studies must be carried out on this aspect.
\end{abstract}

Keywords: Floating system, organic fertilization, seedling production, Zinnia elegans

\section{Introduction}

Zinnia elegans L. is an important ornamental plant as its timeless and classic cut flowers held a prestigious position in the cut flower industry for their versatility, numerous colours and lowmaintenance (Ranjan et al., 2017).

The adoption of production methods that are friendly to the environment is of high priority nowadays. The floating system is a promising alternative type of hydroponic seedling production system, which has not been much studied and disseminated in the flower industry (Barbaro et al., 2015). During the last two decades, the floating system has been used extensively in combination with organic fertilizers for organic production of several horticultural species (AkouminakiIoannidou et al., 2015). Treadwell et al. (2011) observed that basil and spearmint plants grown in a soilless media trough system and fertilized with poultry litter presented similar yields to those received inorganic fertilization.

Therefore, the purposes of this study were to produce seedlings of $Z$. elegans in a floating system as an alternative to the conventional system and to evaluate the influence of organic and inorganic nutrient solution formulations on the seedling growth parameters.

\section{Materials and Methods}

An experiment was conducted in a glasshouse of the Agricultural University of Athens $\left(37^{\circ} 58^{\prime}\right.$ $55.83^{\prime \prime} \mathrm{N}, 23^{\circ} 42^{\prime} 16.69^{\prime \prime} \mathrm{E}$ ) from February to April 2013. For the experiment, carried out according to a completely randomized design, three 
Table 1. Effect of organic and inorganic fertilization on seed germination and $\mathrm{T}_{50}$ values of Zinnia elegans grown in floating system

\begin{tabular}{ccc}
\hline Fertilization & Germination $(\%)$ & $\mathrm{T}_{50}$ (days) \\
\hline F-F & $77.4 \pm 3.2$ & $9.54 \pm 0.18$ \\
\hline C \& C & $76.6 \pm 2.4$ & $10.5 \pm 0.76$ \\
\hline INORG & $82.1 \pm 1.8$ & $9.91 \pm 0.51$ \\
\hline$F_{\text {fertilization }}$ & 1.4215 & 0.8026 \\
\hline$p$-value & $\mathrm{ns}$ & $\mathrm{ns}$ \\
\hline F-test ratios are from ANOVA. ns: not significant. & &
\end{tabular}

Table 2. Effect of organic and inorganic fertilization on height and leaf area per plant of Zinnia elegans seedlings grown in floating system

\begin{tabular}{ccc}
\hline Fertilization & Height $(\mathrm{cm})$ & Leaf area per plant $\left(\mathrm{mm}^{2}\right)$ \\
\hline F-F & $15.1 \pm 0.6 \mathrm{~b}$ & $100.5 \pm 10.3 \mathrm{~b}$ \\
\hline C \& C & $18.6 \pm 0.3 \mathrm{a}$ & $164.9 \pm 15.1 \mathrm{a}$ \\
\hline INORG & $17.6 \pm 0.4 \mathrm{a}$ & $146.1 \pm 14.8 \mathrm{ab}$ \\
\hline$F_{\text {fertilization }}$ & 14.3904 & 5.9862 \\
\hline$p$-value & 0.0051 & 0.0372 \\
\hline F-test ratios are from ANOVA ns: not significant Mean values within
\end{tabular}

F-test ratios are from ANOVA. ns: not significant. Mean values within each column followed by different letters, differ significantly according the LSD test $(\mathrm{p} \leq 0.05)$. SE: Standard Error.

fertilization treatments (one inorganic and two organic), with four replicates per treatment were employed. Specifically, twelve troughs of equal size were used for the floating system: four for each fertilization treatment ( 3 fertilization treatments $\times 4$ troughs). The volume of each through was 150 L. The inorganic fertilization treatment (INORG) consisted of an inorganic water-soluble fertilizer solution containing $63 \mathrm{~g} / 150 \mathrm{~L}$ N-P-K (11-1123 plus $\mathrm{Ca}, \mathrm{Mg}$ and microelements $\mathrm{B}, \mathrm{Cu}, \mathrm{Fe}, \mathrm{Mn}$ Zn) (Fytothreptiki S.A., Athens, Greece) and two fungicides, $30 \mathrm{ml}$ Previcur 72.2 SL (propamocarb) and $30 \mathrm{ml}$ Derosal 51.1 SC (carbedazim) (Bayer CropScience S.A., Athens, Greece). The first organic fertilization treatment (F-F) comprised an organic water-soluble fertilizer, $60 \mathrm{ml} / 150 \mathrm{~L}$ FishFert (2-4-0.5 and other trace elements) (Humofert S.A, Athens, Greece), supplemented with 15 $\mathrm{ml} / 150 \mathrm{~L}$ Trichomic (Trichoderma sp.) (Trichodex S.A., Sevilla, Spain) for root protection. The second organic treatment (C\&C) consisted of 96 $\mathrm{ml} / 150 \mathrm{~L}$ Codaphos (0-30-20) and $111 \mathrm{ml} / 150 \mathrm{~L}$ Codasting (7.2-0-0 plus 9\% w/w free aminoacids) (Sustainable Agro Solutions S.A., Lleida, Spain) and also supplemented with $15 \mathrm{ml}$ Trichomic.

Seeds of Z. elegans were sown in a mixture of peat-perlite $1: 1 \mathrm{v} / \mathrm{v}$ contained in polystyrene floating trays with 176 cells per tray (individual cell volume $11.5 \mathrm{~cm}^{3}$ ). One seed per cell was placed on the surface of the substrate, without additional covering. Totally 2112 Z. elegans seeds where used.

Seedling emergence was recorded every two days after sowing (DAS) and the final germination percentage was evaluated at 20 days. $\mathrm{T}_{50}$ was calculated according to Coolbear et al. (1980). Two months after sowing, 30 seedlings from each fertilization treatment were harvested and the following biometrical characteristics were measured: plant height, leaf area per plant, fresh and dry weight of the plant above-ground parts (shoots and leaves) and roots. Plant weight was measured from the substrate surface to the apical bud of the plant. Leaf area was measured using an automatic leaf area meter (Delta-T Devices Ltd, Burwell, Cambridge, UK). Dry weight was determined after drying for 24 hours at $70^{\circ} \mathrm{C}$.

The experimental data were analyzed using the JMP 8 statistical software (SAS Institute Inc., Cary, USA) according to the completely randomized design (CRD). The significance of the results was tested by one-way ANOVA and differences between means were separated using the $L S D$ test. All comparisons were made at the $5 \%$ level of significance $(\mathrm{p} \leq 0.05)$. 
Table 3. Effect of organic and inorganic fertilization on fresh and dry weight of the plant aboveground parts (shoots and leaves) and roots of Zinnia elegans seedlings grown in floating system

\begin{tabular}{ccccc}
\hline \multirow{2}{*}{ Fertilization } & \multicolumn{2}{c}{ Above-ground parts } & \multicolumn{2}{c}{ Root } \\
\cline { 2 - 4 } & Fresh weight $(\mathrm{g})$ & Dry weight $(\mathrm{g})$ & Fresh weight $(\mathrm{g})$ & Dry weight $(\mathrm{g})$ \\
\hline $\mathrm{F}-\mathrm{F}$ & $5.49 \pm 0.17 \mathrm{~b}$ & $0.57 \pm 0.03 \mathrm{~b}$ & $2.56 \pm 0.24 \mathrm{ab}$ & $0.17 \pm 0.01 \mathrm{ab}$ \\
\hline $\mathrm{C} \& \mathrm{C}$ & $7.16 \pm 0.38 \mathrm{a}$ & $0.84 \pm 0.05 \mathrm{a}$ & $2.76 \pm 0.18 \mathrm{a}$ & $0.22 \pm 0.01 \mathrm{a}$ \\
\hline INORG & $6.34 \pm 0.29 \mathrm{ab}$ & $0.68 \pm 0.02 \mathrm{~b}$ & $1.95 \pm 0.09 \mathrm{~b}$ & $0.15 \pm 0.02 \mathrm{~b}$ \\
\hline$F_{\text {fertilization }}$ & 8.1156 & 12.1622 & 5.2519 & 5.7331 \\
\hline$p$-value & 0.0197 & 0.0077 & 0.0481 & 0.0405 \\
\hline -test ratios are from AN0VA. ns: not significant. Mean values within each column followed by different letters, differ significantly
\end{tabular}

F-test ratios are from ANOVA. ns: not significant. Mean values within each column followed by different letters, differ significantly according the LSD test ( $\mathrm{p} \leq 0.05)$. SE: Standard Error.

\section{Results and Discussion}

Zinnia elegans seeds germinated at a high rate (76.6-82.1\%) in all fertilization treatments with a $\mathrm{T}_{50}$ ranging from 9.54 to 10.50 days (Tab. 1). Although seed germinability and the rate of germination were not significantly affected by fertilization regimes, inorganic fertilization showed a tendency to improve seed germination percentage, presented the higher value $(82.1 \%)$. Similar results were also found in a previous study conducted in spearmint (Akoumianaki-Ioannidou et al., 2015).

The effect of fertilization on the height of Z. elegans seedlings grown in floating system is presented in Table 2. Seedlings fertilized organically with Codaphos and Codasting (C \& C) were taller $(18.6 \mathrm{~cm})$ than those produced with inorganic fertilizer $(\mathrm{N}-\mathrm{P}-\mathrm{K})(17.6 \mathrm{~cm})$ and FishFert $(15.1 \mathrm{~cm})$; however, the difference between $\mathrm{C}$ $\& \mathrm{C}$ and inorganic fertilization was not statistically significant. Regarding leaf area per plant, seedlings grown with C \& C had also greater values (164.9 $\left.\mathrm{mm}^{2}\right)$ than those grown with N-P-K $\left(146.1 \mathrm{~mm}^{2}\right)$ and Fish-Fert (100.5 $\mathrm{mm}^{2}$ ) (Tab. 2).

The fresh weight of above-ground parts was significantly influenced by the different fertilization regimes (Tab. 3). Plants fed with $\mathrm{C}$ $\& \mathrm{C}$ had higher fresh weight of shoots and leaves $(7.16 \mathrm{~g})$ than those receiving N-P-K $(6.34 \mathrm{~g})$ and Fish-Fert (5.49 g). Similarly, fertilization had also significant effect on the accumulation of dry mass in Z. elegans plants with C \& C presenting the highest weight $(0.84 \mathrm{~g})$.

Root fresh weight observed in C \& $\mathrm{C}$ was significantly higher $(2.76 \mathrm{~g})$ compared to Fish-Fert (2.56 g) and N-P-K (1.95 g) treatments. Root dry weight results were similar to fresh weight results, with the highest value observed in seedings fertilized with C \& C $(0.22 \mathrm{~g})$ and the lowest $(0.15$ g) under inorganic fertilization.

Application of Codaphos and Codasting (C \& C) in floating system resulted in better development and higher biomass accumulation of the aboveground parts of Z. elegans (taller plants, with larger leaves and higher fresh and dry weight of shoots and leaves). The results of the present study and those of other studies on several plant species, indicate that organic fertilization in floating production systems may sufficiently cover the nutrient requirements of the produced plantlets (Bilalis et al., 2009; Akoumianaki-Ioannidou et al., 2015). In addition, Z. elegans seedlings fed with C \& C developed a rich root system with higher fresh and dry weight, compared to Fish-Fert and $\mathrm{N}-\mathrm{P}-\mathrm{K}$. For this reason, the seedlings fertilized with C \& C are expected to be better established after transplanting, as they presented an extensive root system. Akouminaki-Ioannidou et al. (2015) found that both C \& C and N-P-K fertilization had equal effect in basil and spearmint.

As a conclusion, the present study showed that organic fertilization with Codaphos and Codasting could successfully be used for the production of Z. elegans seedlings in a floating system; however, further studies must be carried out on this aspect.

\section{References}

1. Akoumianaki-Ioannidou A, Rasouli M, Podaropoulou L, Karapanos I, Bilalis D (2015). Effects of cultivation system and fertilization on seedling production of Ocimum basilicum L. and Mentha spicata L. Notulae Botanicae Horti Agrobotanici Cluj-Napoca, 43(1): 131-137.

2. Barbaro LA, Delucchi G, Karlanian MA (2015). Production of seedlings of petunia (Petunia hybrida) in a floating system. Revista de Investigaciones Agropecuarias, 41(2): 208-214.

3. Bilalis D, Kanatas P, Patsiali S, Konstantas A, Akoumianakis K (2009). Comparison between conventional and organic 
floating systems for lettuce and tomato (Lactuca sativa and Lycopersicon esculentum) seedling production. Journal of Food, Agriculture \& Environment, 7(2): 623-628.

4. Coolbear P, Grierson D, Heydecker W (1980). Osmotic pre-sowing treatments and nucleic acid accumulation in tomato seeds (Lycopersicon lycopersicum). Seed Science and Technology, 8: 289-303.

5. Ranjan P, Ranjan JK, Bag MK, Misra S (2017). Zinnia (Family: Asteraceae). In R. L. Misra, S. Misra (Eds.),
Commercial Ornamental Crops: Cut Flowers (pp. 535544). UK: Kruger Brentt Publisher LTD.

6. Treadwell DD, Hochmuth GJ, Hochmuth RC, Simonne EH, Sargent SA, Davis LL, Laughlin WL, Berry A (2011). Organic fertilization programs for greenhouse fresh-cut basil and spearmint in a soilless media trough system. HortTechnology, 21: 162-169. 